\title{
Expectations and Perceptions of Overseas Students towards Service Quality of Higher Education Institutions in Scotland
}

\author{
Essam Ibrahim ${ }^{1}$, Lee Wei Wang ${ }^{2} \&$ Abeer Hassan ${ }^{3}$ \\ ${ }^{1}$ Business School, University of Edinburgh, Edinburgh, UK \\ ${ }^{2}$ QUANTA Computer Inc., Taiwan \\ ${ }^{3}$ West of Scotland University, Scotland \\ Correspondence: Essam Ibrahim, Business School, University of Edinburgh, 29 Buccleuch Place, Edinburgh, \\ EH8 9JS, UK. E-mail: essam.ibrahim@ed.ac.uk
}

Received: October 1, 2012

Accepted: April 23, $2013 \quad$ Online Published: May 17, 2013

doi:10.5539/ibr.v6n6p20

URL: http://dx.doi.org/10.5539/ibr.v6n6p20

\begin{abstract}
The study uses the SERVQUAL construct to measure the expectations and perceptions of overseas students towards service quality of higher education institutions in Scotland. Structured questionnaire was distributed to 200 postgraduate and undergraduate overseas students from China and Taiwan studying at Glasgow, Strathclyde, Stirling, West of Scotland (UWS) and Glasgow Caledonian Universities. A set of 129 completed and usable questionnaires was used in the analysis and a number of advanced statistical techniques were employed. The findings revealed a perceptual gap between students' expectations and their actual experience of the education services delivered to them by higher education institutions in Scotland. Detailed findings and managerial implications are discussed.
\end{abstract}

Keywords: service quality, higher education, customer expectations, customer satisfaction

\section{Introduction}

Quality of service has received greater attention from marketing academics and practitioners in the past few decades. Academics, in particular, were very much interested in the measurement of service quality (e.g., Bitner 1990; Cronin \& Taylor 1992; Parasuraman, Zeithaml \& Berry 1985, 1988, 1994). The research studies by Parasuraman et al., $(1985,1988)$ have suggested five dimensions of service quality (i.e., reliability, responsiveness, assurance, tangibles and empathy), which have been widely used in later years in measuring the quality of service in many industries. Utilising these five dimensions, industry managers have made several attempts to use the SERVQUAL instrument in measuring customer perceptions of service quality and identifying the perceptual gap between service provider and service recipients. The relative importance of each dimension of the SERVQUAL construct is subjective and relativistic because it is based on customers' values and beliefs that might change from one individual to another and from one culture to another (Furrer, Liu, \& Sudharshan, 2000). Some of the determinants of customer expectations of services quality as identified by Zeithmal, Berry and Parasuraman (1993) are customer's personal needs: physical, social and psychological. These dimensions are strongly influenced by the social and culture of customers. Thus culture has an important influence on customer's expectations and perceptions of service quality.

We, therefore, study the expectations and perceptions of overseas students towards the quality of education services. The present study contributes to our understanding of what overseas students expect to receive when they pay for a degree abroad and how to improve the quality of educational service to satisfy their requirements and improve their overall perceptions.

The study has three key objectives. Firstly we measure the expectations of overseas students towards the service quality of Scottish higher education. Second to measure their actual experience (perceptions) of service quality they received from the higher education institutions in Scotland. We then use the confirmation/disconfirmation model to find out if there is a significant gap between expectations and perceptions of overseas students about the quality of education services delivered to them.

\section{Literature Review}

Perceived quality, whether in reference to a product or service, has been defined by Arnould, Price, Zinkhan 
(2002) as "the consumer's evaluative judgment about an entity's overall excellence or superiority in providing desired benefit" (p742). Coulthard (2004) defined perceived quality as "the consumers' judgment about an entity's overall excellence or superiority, which can be viewed as distinct from objective quality in as much as it is a form of attitude, related in part to satisfaction, and resulting from a comparison of expectations with perceptions of performance" ( $\mathrm{p} 480)$.

Research by Lehtinen and Lehtinen (1982) and Parasuraman, Zeithaml and Berry (1985) note that the quality of service, as perceived by the consumers, originates from a comparison of what consumers believe about company's offerings (i.e. their perceptions) and their expectations of what the companies ought to offer. Parasuraman et al. (1985) created the SERVQUAL construct as a multiple-item scale for measuring customers' perceptions of service quality. In their subsequent paper (1988) they reduced the original 10-dimension construct to five dimensions model to include tangibility, reliability, responsiveness, assurance and empathy. They designed an instrument of 22 items to measure consumer's expectations and perceptions of the five dimensions, where each dimension was represented by four or five statements.

\subsection{SERVQUAL Application in Higher Education Sector}

Seymour (1992) used the SERVQUAL model to measure service quality of US education institutions from student perspectives. Similarly, Ruby (1996) employed the five dimensions of SERVQUAL to examine students' satisfaction in the USA. Tomkovick, Alkhatib, Baradwaj and Jones (1996) have implemented the model to assess quality of service quality as perceived by non-USA students attending USA business schools. Away from USA, Soutar, McNeil and Lim (1996) examined foreign students' perceptions of service quality delivered by a number of Australian educational institutions. Scoutar and McNeil (1996) conducted another study in Australia to measure service quality from two different perspectives of teaching and administration employees. Suba (1997) conducted a survey into elementary schools to assess expectation and satisfaction factors with the quality of education service provided to students. The construct of Suba (1997), while used Parasuraman et al. (1985) SERVQUAL model, it was revised to include dimensions such as physical attributes, importance of personal demand, teaching, community participation and learning outcome. Kerlin (2000) used a revised version of the model to measure the quality of service process of student educational support systems at the Everett Community College in Washington (USA).

In comparison to the USA, there seems to be a limited number of studies that has been undertaken in the UK to measure service quality of higher education institutions. For example, Hill (1997) developed a longitudinal study in the 1990s targeting accounting undergraduates at a provincial British university, and found that some service dimensions were crucial to the successful completion for many students. Aldridge and Rowley (1998) conducted a study to examine students' satisfaction of the educational services delivered at the University of Central England. Focus group methodology was used to inform the design of a questionnaire to measure undergraduate student's perceptions. Students' expectations were not examined in this study. In a study by Cuthbert (1996) it was suggested that the various elements of service quality should be revised by course directors to develop a specific construct for higher education. A modified version of the SERVQUAL model was tested on a sample of students at Manchester Metropolitan University and the result showed that the mean of perceptions of each dimension surpasses that of expectations except for tangibles.

\subsection{Service Performance and Criticism against SERVQUAL}

Churchill, Brown and Peter (1993) argue against the validity of SERVQUAL claiming that the construct is only supported by little empirical/theoretical evidence and that the scale failed to gain discriminant validity from its components. In addition, Cronin and Taylor (1992) believe that the SERVPERF, an un-weighted performance-based scale, can provide better results when measuring service quality compared to SERVQUAL. Although the debate between supporters of SERVQUAL and SERVPERF has lasted for a long period of time, the SERVQUAL is still the most practical model for measuring service quality (Cuthbert, 1996; Buttle, 1995). However, it should be noted that the use of SERVQUAL construct in measuring service quality of education seemed to employ the model in measuring single phenomenon; either students expectations or satisfaction, but not the two. The measurement of both to identify the perceptual gap from the students' view seems to have received little attention in service marketing research.

\section{Methodology}

\subsection{Scale Measurement}

The questionnaire of the present study was developed based on Parasuraman et al. (1994) SERVQUAL five dimensions model, and was divided into three sections. While section one was designed to measure overseas 
students' expectations of Scottish higher education services, section two was to measure students' perceptions of the services delivered to them. Finally section three aimed at collecting some personal information from respondents. We used Hoffman and Bateson's (1997) questionnaire template of service quality measurement to operationalise our service quality variables with some adjustment to make it applicable to higher education service. We measured students' expectations and perceptions in this study using 22-items for each measurement where respondents were asked to circle the category that best matched their opinion (Centeno, Harker, Ibrahim \& Wang, 2008). Similar to Hill (1997) in using the 'perceived importance' as an indicator of expectations, we used the 5-point Likert scale of 'very important - very unimportant' to measure expectations.

\subsection{Sample}

According to the Scottish Higher Education Funding Council (SHEFC), around 15\% of higher education students in Scotland are from countries outside the UK (Baseline report, International students and links, 2005). The report revealed that China has the third largest population of overseas students studying in Scotland. It was reported that the number of Chinese students in the UK has almost doubled in the past decade. It was also revealed that the number of Taiwanese students coming to study in Scotland has risen dramatically in past years to contribute some to the Scottish economy. Based on the above, we choose to conduct our survey with a sample from overseas Chinese and Taiwanese students studying in the Scottish Universities. The sample size for this research was calculated using Malhotra's (2004) formula:

$$
n=\frac{\pi(1-\pi) z^{2}}{D^{2}}
$$

The calculation of the above formula, with $95 \%$ confidence level, revealed that the required sample size for this research was 200.0754. Therefore, 200 questionnaires were distributed to overseas Chinese and Taiwanese students attending Strathclyde, Glasgow, Stirling, Glasgow Caledonian and UWS universities. We could not access the official list of overseas students in Registry offices at the five universities because of data protection laws. We were only able to obtain the total number of overseas students at each university, therefore we implemented proportional stratified sampling procedure (Kumar, Aaker \& Day, 2002). Since the sample size identified in this research was 200 respondents, a $13.661 \%$ directly proportional stratified sample size was employed. A set of 129 completed and usable questionnaires were used. The detailed sample groups and sub-group are illustrated in Table 1.

The questionnaire was pre-tested with a group of 10 Chinese and Taiwanese students who commented positively on most of the questions, but suggested minor changes to few questions (e.g., Q.13, 20 and 22). Their comments were taken into account and the questionnaire was refined in terms of wording, layout and style before launching the survey. Snowballing was our method of data collection from the few contacts we have at the chosen universities.

A number of statistical techniques were used in the analysis to: (a) measure the reliability of the scale-items, (b) examine students' expectations, perceptions and SERVAUAL gap, and (c) test the study hypothesis. We defined the null $(\boldsymbol{H O})$ and alternate $(\boldsymbol{H} \mathbf{1})$ hypothesis as follows:

"NO significant difference between the mean scores for overseas students' expectations and perceptions of service quality of specific items".

"There is significant difference between the mean score for overseas students' expectations and perceptions of service quality of specific items".

\section{Findings and Discussion}

The objectives of this study were to measure overseas students' expectations and perceptions towards the service quality of Scottish higher education institutions and to gain further insight into the overall service quality using the SERVQUAL confirmation/disconfirmation model. Our sample comprised of 45 students from Strathclyde, 31 from Glasgow, 27 from Sterling, 14 from UWS and 12 from Glasgow Caledonian Universities. Table 1 below provides a brief descriptive analysis of the demographic characteristics of the sample. 
Table 1. Descriptive analysis of the sample

\begin{tabular}{|c|c|c|c|c|}
\hline \multicolumn{3}{|l|}{ Characteristics } & \multirow{2}{*}{ Number } & \multirow[t]{2}{*}{ Percentage $(\%)$} \\
\hline Institute & Group size & $\begin{array}{l}13.661 \% \text { proportional stratified } \\
\text { sample size }\end{array}$ & & \\
\hline Strathclyde & 327 & $44.67(45)$ & 45 & 34.9 \\
\hline Glasgow & 527 & $71.99(72)$ & 31 & 24.0 \\
\hline Stirling & 251 & $34.28(34)$ & 27 & 20.9 \\
\hline West of Scotland (UWS) & 276 & $37.7(38)$ & 14 & 10.9 \\
\hline Glasgow Caledonian & 83 & $11.33(11)$ & 12 & 9.3 \\
\hline Total & 1464 & $199.97(200)$ & 129 & $100 \%$ \\
\hline \multicolumn{5}{|l|}{ Gender } \\
\hline Male & & & 45 & 34.8 \\
\hline Female & & & 84 & 65.1 \\
\hline \multicolumn{5}{|l|}{ Nationality } \\
\hline China & & & 51 & 39.5 \\
\hline Taiwan & & & 78 & 60.4 \\
\hline \multicolumn{5}{|l|}{ Degree } \\
\hline Postgraduate & & & 122 & 94.5 \\
\hline Undergraduate & & & 7 & 5.42 \\
\hline \multicolumn{5}{|l|}{ Range of age } \\
\hline Under 18 & & & 0 & 0 \\
\hline $18-21$ & & & 6 & 4.65 \\
\hline $22-25$ & & & 51 & 39.5 \\
\hline $26-29$ & & & 43 & 33.3 \\
\hline $30-33$ & & & 23 & 17.8 \\
\hline 34 and above & & & 6 & 4.65 \\
\hline \multicolumn{5}{|l|}{ Subjects } \\
\hline Accountancy \& Finance & & & 8 & 6.2 \\
\hline Aeronautical \& Manufactu & ring & & 1 & 0.77 \\
\hline Art \& Design & & & 1 & 0.77 \\
\hline Business Studies & & & 69 & 53.4 \\
\hline Chemistry & & & 1 & 0.77 \\
\hline Communication \& Media & & & 3 & 2.32 \\
\hline Computer Science & & & 3 & 2.32 \\
\hline Economics & & & 4 & 3.1 \\
\hline Education & & & 2 & 1.55 \\
\hline Electrical Engineering & & & 2 & 1.55 \\
\hline Hotel and Hospitality & & & 7 & 5.42 \\
\hline Linguistics & & & 2 & 1.55 \\
\hline Medicine (and other Medic & ubjects) & & 6 & 4.65 \\
\hline Politics & & & 1 & 0.77 \\
\hline Psychology & & & 2 & 1.55 \\
\hline Pharmacology & & & 0 & 0 \\
\hline Others & & & 17 & 13.1 \\
\hline
\end{tabular}

\subsection{Reliability Analysis}

Reliability analysis measures the degree to which scale-items are reliable to generate consistent results (Kumar, 2002; Zikmund, 1997). We used Alpha Cronbach ( $\boldsymbol{\alpha})$, which examines the extent to which a set of items can be trusted in measuring a single latent variable (Guilford, 1978). The reliability test for the "expectations" 22-items indicated that the estimated ' $\boldsymbol{\alpha}$ ' for four dimensions (i.e., tangibility, reliability, assurance and empathy) fall within the range of $0.7-0.9$, while the estimated ' $\alpha$ ' of the responsiveness was at 0.66 . On the other hand, the reliability test for the "perceptions" items indicated that the three dimensions of responsiveness, reliability and assurance have estimated ' $\boldsymbol{\alpha}$ ' falling in the range 0.8181-0.814, while the ' $\boldsymbol{\alpha}$ ' of tangibility and empathy dimensions were in the range of $0.60-0.70$. The test revealed that the scale-items used in this research were reliable (see Table 2A \& 2B). 
Table 2A. Reliability analysis for expectation items

\begin{tabular}{|c|c|c|c|}
\hline Dimension & $\begin{array}{l}\text { Question } \\
\text { No. }\end{array}$ & SERVQUAL measurement items & $\begin{array}{l}\text { Cronbach } \\
\boldsymbol{\alpha}\end{array}$ \\
\hline \multirow[t]{4}{*}{ Tangibility } & 1 & Use of advanced and modern teaching and IT facilities & 0.7131 \\
\hline & 2 & Appealing physical appearance of buildings and class rooms & \\
\hline & 3 & Faculty and other staff are of professional character & \\
\hline & 4 & Interesting and easy to understand learning materials & \\
\hline \multirow[t]{5}{*}{ Reliability } & 5 & Fair and consistent assessment of students work & 0.804 \\
\hline & 6 & Sincere intention in resolving students problems and concerns & \\
\hline & 7 & Fulfilling students' requirements at the right time & \\
\hline & 8 & Fulfilling previous commitments/promises to students & \\
\hline & 9 & Promoting error-free records and documentations & \\
\hline \multirow[t]{4}{*}{ Responsiveness } & 10 & $\begin{array}{l}\text { Provision of accurate information re educational services e.g., timetable, meetings and events, } \\
\text { assignment/exam result, etc. }\end{array}$ & 0.6633 \\
\hline & 11 & Provision of prompt response/feedback to students & \\
\hline & 12 & Willingness to provide academic assistance/help to students & \\
\hline & 13 & Willingness to help students improving their personal and communications skills & \\
\hline \multirow[t]{4}{*}{ Assurance } & 14 & Provision of professional skills required for good academic performance and for future employment & 0.8248 \\
\hline & 15 & Money spent on the degree should reflect quality of education service offered & \\
\hline & 16 & Wide provision of various support services to foreign students & \\
\hline & 17 & Academics are knowledgeable on students subject of study & \\
\hline \multirow[t]{5}{*}{ Empathy } & 18 & Staff understand the range of specific challenges facing foreign students & 0.8361 \\
\hline & 19 & University opening hours are convenient and well publicized & \\
\hline & 20 & Provision of emergency services to foreign students & \\
\hline & 21 & Provision of tailored advice to foreign students upon arrival on matters inside and outside university life & \\
\hline & 22 & Good understanding of foreign students' specific needs & \\
\hline
\end{tabular}

Table 2B. Reliability analysis for perception items

\begin{tabular}{|c|c|c|c|}
\hline Dimension & $\begin{array}{l}\text { Question } \\
\text { No. }\end{array}$ & SERVQUAL measurement items & $\begin{array}{l}\text { Cronbach } \\
\boldsymbol{\alpha}\end{array}$ \\
\hline \multirow[t]{4}{*}{ Tangibility } & 1 & My university has advanced and modern teaching and IT facilities & 0.6461 \\
\hline & 2 & My university has appealing physical appearance of buildings and class rooms & \\
\hline & 3 & Faculty and other staff at my university are of professional character & \\
\hline & 4 & My university provides interesting and easy to understand learning materials & \\
\hline \multirow[t]{5}{*}{ Reliability } & 5 & Academics provide fair and consistent assessment to students work & 0.8181 \\
\hline & 6 & My university shows sincere intention in resolving students problems and concerns & \\
\hline & 7 & My university fulfils students' requirements at the right time & \\
\hline & 8 & My university fulfils its commitments/promises to students & \\
\hline & 9 & My university promotes error-free records and documentations & \\
\hline \multirow[t]{4}{*}{ Responsiveness } & 10 & $\begin{array}{l}\text { My university provides accurate information re educational services e.g., timetable, meetings and } \\
\text { events, assignment/exam result, etc }\end{array}$ & 0.8073 \\
\hline & 11 & My university provides prompt response/feedback to students & \\
\hline & 12 & Staff at my university are willing to provide academic assistance to students when needed & \\
\hline & 13 & Staff at my university are willing to help students improving their personal and communications skills & \\
\hline \multirow[t]{4}{*}{ Assurance } & 14 & $\begin{array}{l}\text { Students are given the professional skills they require for good academic performance and for future } \\
\text { employment }\end{array}$ & 0.814 \\
\hline & 15 & I am confident that the money I spent on the degree worth the quality of education service offered & \\
\hline & 16 & My university offers various support services to foreign students & \\
\hline & 17 & Academics at my university are knowledgeable on students subject of study & \\
\hline \multirow[t]{5}{*}{ Empathy } & 18 & Staff at my university understand the range of specific challenges facing foreign students & 0.6036 \\
\hline & 19 & My university has convenient opening hours which are well publicized & \\
\hline & 20 & My university provides emergency services to foreign students & \\
\hline & 21 & $\begin{array}{l}\text { My university gives tailored advice to foreign students upon arrival on matters inside and outside } \\
\text { university life }\end{array}$ & \\
\hline & 22 & Staff at my university understand the specific needs of foreign students & \\
\hline
\end{tabular}


We measured overseas students' expectations on a 5-point Likert scale where respondents have been asked to indicate the degree of importance of the 22 expectations statements. The mean scores were ranked from high to low as shown in Table 3. Overseas students perceived the following five items as highly important in shaping their expectations of service quality of higher education institutions:

- staff (academic and admin) must be willing to assist/help students (Responsiveness);

- university must be keen to resolve students' problems and concerns (Reliability);

- academics must be fair and consistent when assessing student material (Reliability);

- academics must be knowledgeable on students' subject of study (Assurance);

- tuition fee must reflect quality of all services in the institution (Assurance).

The above results were generally consistent with SHEFC's report where $58 \%$ of overseas students expect to be given personal help, learning support and guidance from academic and non-academic staff. This corresponds to the claim by Furrer, Liu, and Sudharshan (2000) that students from different cultures may have different views when evaluating the service offered to them. However when it comes to the reliability and responsibility of staff, all students seem to have same attitude towards them. The results of this study help the higher education institutions in Scotland to pay particular attention to those attributes perceived by students as of highest importance.

Table 3. Mean and rank of overseas students' expectations

\begin{tabular}{|c|c|c|c|c|}
\hline Dimension & $\begin{array}{l}\text { Question } \\
\text { No. }\end{array}$ & SERVQUAL measurement items & $\begin{array}{l}\text { Mean } \\
\text { (Expectations) }\end{array}$ & Rank \\
\hline \multirow[t]{4}{*}{ Tangibility } & 1 & Use of advanced and modern teaching and IT facilities & 4.0155 & 8 \\
\hline & 2 & Appealing physical appearance of buildings and class rooms & 3.4341 & 21 \\
\hline & 3 & Faculty and other staff are of professional character & 2.9922 & 22 \\
\hline & 4 & Interesting and easy to understand learning materials & 3.7209 & 18 \\
\hline \multirow[t]{5}{*}{ Reliability } & 5 & Fair and consistent assessment of students work & 4.2093 & 3 \\
\hline & 6 & Sincere intention in resolving students problems and concerns & 4.2248 & 2 \\
\hline & 7 & Fulfilling students' requirements at the right time & 3.8527 & 16 \\
\hline & 8 & Fulfilling previous commitments/promises to students & 3.9845 & 9 \\
\hline & 9 & Promoting error-free records and documentations & 3.7442 & 17 \\
\hline \multirow[t]{4}{*}{ Responsiveness } & 10 & $\begin{array}{l}\text { Provision of accurate information re educational services e.g., timetable, meetings and } \\
\text { events, assignment/exam result, etc }\end{array}$ & 3.6667 & 20 \\
\hline & 11 & Provision of prompt response/feedback to students & 3.969 & 11 \\
\hline & 12 & Willingness to provide academic assistance/help to students & 4.6124 & 1 \\
\hline & 13 & Willingness to help students improving their personal and communications skills & 3.9457 & 13 \\
\hline \multirow[t]{4}{*}{ Assurance } & 14 & $\begin{array}{l}\text { Provision of professional skills required for good academic performance and for future } \\
\text { employment }\end{array}$ & 3.9767 & 10 \\
\hline & 15 & Money spent on the degree should reflect quality of education service offered & 4.2093 & 4 \\
\hline & 16 & Wide provision of various support services to foreign students & 4.0543 & 7 \\
\hline & 17 & Academics are knowledgeable on students subject of study & 4.1163 & 5 \\
\hline \multirow[t]{5}{*}{ Empathy } & 18 & Staff understand the range of specific challenges facing foreign students & 3.9457 & 14 \\
\hline & 19 & University opening hours are convenient and well publicized & 3.938 & 15 \\
\hline & 20 & Provision of emergency services to foreign students & 4.0853 & 6 \\
\hline & 21 & $\begin{array}{l}\text { Provision of tailored advice to foreign students upon arrival on matters inside and } \\
\text { outside university life }\end{array}$ & 3.969 & 12 \\
\hline & 22 & Good understanding of foreign students' specific needs & 3.7054 & 19 \\
\hline
\end{tabular}

We measured the perceptions of overseas students using 22-statements on a 5-point Likert scale where respondents have been asked to indicate the extent to which they agree/disagree with each statement. We ranked the mean scores of the 22-items from high to low and found the following 5 attributes to be perfectly performed by universities in Scotland as perceived by overseas students (see Table 4):

- university opening hours are convenient to students and well publicised (Empathy);

- academics at my university are of professional character (Tangibility);

- my university has advanced and modern facilities available for students' use (Tangibility); 
- learning material in my university is interesting and easy to understand (Tangibility);

- my university provides a wide range of support services to students (Assurance).

These results are relatively similar to SHEFC's report, especially in regards to the importance of modern facilities, good learning material and professional manner of staff. These items were perceived by overseas students as the most important attributes reflecting the better education service performance offered by higher education universities in Scotland.

Table 4. Mean and ranking of overseas students' perceptions

\begin{tabular}{|c|c|c|c|c|}
\hline Dimension & $\begin{array}{l}\text { Question } \\
\text { No. }\end{array}$ & SERVQUAL measurement items & $\begin{array}{l}\text { Mean } \\
\text { (Perceptions) }\end{array}$ & Rank \\
\hline \multirow[t]{4}{*}{ Tangibility } & 1 & My university has advanced and modern teaching and IT facilities & 3.6977 & 3 \\
\hline & 2 & My university has appealing physical appearance of buildings and class rooms & 3.5659 & 7 \\
\hline & 3 & Faculty and other staff at my university are of professional character & 3.7209 & 2 \\
\hline & 4 & My university provides interesting and easy to understand learning materials & 3.6667 & 4 \\
\hline \multirow[t]{5}{*}{ Reliability } & 5 & Academics provide fair and consistent assessment to students work & 3.5349 & 9 \\
\hline & 6 & My university shows sincere intention in resolving students problems and concerns & 3.3721 & 14 \\
\hline & 7 & My university fulfils students' requirements at the right time & 3.0698 & 22 \\
\hline & 8 & My university fulfils its commitments/promises to students & 3.1705 & 20 \\
\hline & 9 & My university promotes error-free records and documentations & 3.2171 & 18 \\
\hline \multirow[t]{4}{*}{ Responsiveness } & 10 & $\begin{array}{l}\text { My university provides accurate information re educational services e.g., timetable, } \\
\text { meetings and events, assignment/exam result, etc }\end{array}$ & 3.5039 & 10 \\
\hline & 11 & My university provides prompt response/feedback to students & 3.186 & 19 \\
\hline & 12 & Staff at my university are willing to provide academic assistance to students when needed & 3.5659 & 8 \\
\hline & 13 & $\begin{array}{l}\text { Staff at my university are willing to help students improving their personal and } \\
\text { communications skills }\end{array}$ & 3.2248 & 17 \\
\hline \multirow[t]{4}{*}{ Assurance } & 14 & $\begin{array}{l}\text { Students are given the professional skills they require for good academic performance and } \\
\text { for future employment }\end{array}$ & 3.3023 & 15 \\
\hline & 15 & $\begin{array}{l}\text { I am confident that the money I spent on the degree worth the quality of education service } \\
\text { offered }\end{array}$ & 3.1395 & 21 \\
\hline & 16 & My university offers various support services to foreign students & 3.6434 & 5 \\
\hline & 17 & Academics at my university are knowledgeable on students subject of study & 3.4961 & 11 \\
\hline \multirow[t]{5}{*}{ Empathy } & 18 & Staff at my university understand the range of specific challenges facing foreign students & 3.4419 & 12 \\
\hline & 19 & My university has convenient opening hours which are well publicized & 3.9612 & 1 \\
\hline & 20 & My university provides emergency services to foreign students & 3.3798 & 13 \\
\hline & 21 & $\begin{array}{l}\text { My university gives tailored advice to foreign students upon arrival on matters inside and } \\
\text { outside university life }\end{array}$ & 3.6124 & 6 \\
\hline & 22 & Staff at my university understand the specific needs of foreign students & 3.2326 & 16 \\
\hline
\end{tabular}

\subsection{Perceptions - Expectation Gap}

To find out if there is a gap between students' expectations and perceptions and whether the gap is positive/negative, we compared the mean scores of the 22 items of each of them applying an 'item-by-item' analysis. The results as shown in Table 5 were generally unsatisfactory. The mean score of each perception item was below the expectation mean score, except for three items 2, 3 and 19. Similar to Hill's study (1997), we found a clear gap between the mean scores of students' perception and expectation in relation to the prompt response and feedback' provided to students. This could imply that the Scottish Universities need to pay greater attention to improve staff's response/feedback to students. 
Table 5. Service confirmation (Gap $=$ P-E) by items

\begin{tabular}{lllllll}
\hline Dimension & Question No. & $\begin{array}{l}\text { Mean } \\
\text { (Perceptions) }\end{array}$ & $\begin{array}{l}\text { Mean } \\
\text { (Expectations) }\end{array}$ & SERVQUAL Confirmation (gap=P-E) & Rank & P value \\
\hline Tangibility & 1 & 3.6977 & 4.0155 & -0.3178 & 17 & $0.013 *$ \\
& 2 & 3.5659 & 3.4341 & 0.1318 & 21 & 0.239 \\
& 3 & 3.7209 & 2.9922 & 0.7287 & 22 & $0.000 * * *$ \\
& 4 & 3.6667 & 3.7209 & -0.0542 & 19 & 0.627 \\
\hline Reliability & 5 & 3.5349 & 4.2093 & -0.6744 & 10 & $0.000 * * *$ \\
& 6 & 3.3721 & 4.2248 & -0.8527 & 3 & $0.000 * * *$ \\
& 7 & 3.0698 & 3.8527 & -0.7829 & 6 & $0.000 * * *$ \\
& 8 & 3.1705 & 3.9845 & -0.8140 & 4 & $0.000 * * *$ \\
& 9 & 3.2171 & 3.7442 & -0.5271 & 12 & $0.000 * * *$ \\
\hline Responsiveness & 10 & 3.5039 & 3.6667 & -0.1628 & 18 & 0.179 \\
& 11 & 3.186 & 3.969 & -0.7830 & 5 & $0.000 * * *$ \\
& 12 & 3.5659 & 4.6124 & -1.0465 & 2 & $0.014 * *$ \\
& 13 & 3.2248 & 3.9457 & -0.7209 & 7 & $0.000 * * *$ \\
\hline Assurance & 14 & 3.3023 & 3.9767 & -0.6744 & 9 & $0.000 * * *$ \\
& 15 & 3.1395 & 4.2093 & -1.0698 & 1 & $0.000 * * *$ \\
& 16 & 3.6434 & 4.0543 & -0.4109 & 15 & $0.000 * * *$ \\
& 17 & 3.4961 & 4.1163 & -0.6202 & 11 & $0.000 * * *$ \\
\hline Empathy & 18 & 3.4419 & 3.9457 & -0.5038 & 13 & $0.000 * * *$ \\
& 19 & 3.9612 & 3.938 & 0.0232 & 20 & 0.952 \\
& 20 & 3.3798 & 4.0853 & -0.7055 & -0.3566 & $0.000 * * *$ \\
& 21 & 3.6124 & 3.969 & -0.4728 & $0.000 * * *$ \\
& 22 & 3.2326 & 3.7054 & & 16 & $0.000 * * *$ \\
\hline
\end{tabular}

Notes: Significant level $=* \mathrm{p} \leq 0.05 * * \mathrm{p} \leq 0.01 * * * \mathrm{p} \leq 0.001$.

The paired-sample t-test was used to test the research hypothesis. The result above in Table 5 indicates that item 1 for tangibility dimension showed significant difference between overseas students' expectations and perceptions at $p \leq 0.05$, while item 3 for tangibility dimension, items $5-9$ for reliability dimension, items 11 and 13 for responsiveness dimension, items 14-17 for assurance dimension and items 18, 20, 21 and 22 for empathy dimension were all significant at $p \leq 0.001$. Item 12 was the only one that is significant at $p \leq 0.01$. Therefore, we can conclude that there is significant difference between overseas students' expectations and perceptions of the higher education services offered to them by Scottish universities, thus we tend to accept the alternate hypothesis (H1) for all items, but item 2, 4, 10 and 19. For these four particular items the significance level being at $\mathrm{p} \leq 0.5$ implies that $N O$ significant difference between students' expectations and perceptions, thus we tend to accept the null hypothesis $(\boldsymbol{H O})$ for these four items.

We applied the same procedure again but this time in a 'dimension-by-dimension' analysis to ascertain the gap between students' expectations and perceptions. We simply summed the mean scores of each dimension for both perceptions $[\mathrm{P}]$ and expectations $[\mathrm{E}]$ and divided by the total number of items related to a single dimension. We then compared them together applying the following simple equation $[\mathrm{P} 1+\mathrm{P} 2+\mathrm{P} 3+\mathrm{P} 4 \div 4-\mathrm{E} 1+\mathrm{E} 2+\mathrm{E} 3+\mathrm{E} 4$ $\div 4$ ] to find out the overall quality of educational service delivered by Scottish universities (Centeno et al., 2008). The results shown in Table 6 were unsatisfactory because the mean scores of students' perceptions were lower than the mean scores of expectations for each dimension.

Table 6. Service confirmation $(\mathrm{Gap}=\mathrm{P}-\mathrm{E})$ by dimensions

\begin{tabular}{llllllll}
\hline Dimension & $\begin{array}{l}\text { Question } \\
\text { No }\end{array}$ & \multicolumn{2}{l}{ Perceptions } & \multicolumn{2}{l}{ Expectations } & SERVQUAL \\
\cline { 3 - 7 } & Mean & $\begin{array}{l}\text { Standard } \\
\text { Deviation }\end{array}$ & Mean & $\begin{array}{l}\text { Standard } \\
\text { Deviation }\end{array}$ & Rank \\
\hline Tangibility & $1-4$ & 3.2268 & 0.8426 & 3.5407 & 0.9443 & -0.3139 & 5 \\
Reliability & $5-9$ & 3.2729 & 0.8703 & 4.0031 & 0.9491 & -0.7302 & 1 \\
Responsiveness & $10-13$ & 3.3702 & 0.9291 & 4.0484 & 1.4309 & -0.6782 & 3 \\
Assurance & $14-17$ & 3.3953 & 0.8866 & 4.0891 & 0.9823 & -0.6938 & 2 \\
Empathy & $18-22$ & 3.5256 & 1.094 & 3.9287 & 0.9327 & -0.4031 & 4 \\
\hline
\end{tabular}


As seen in Table 6 reliability has been perceived by overseas students as the worst service dimension [P-E $=$ $-0.7302]$, while tangibility dimension showed the least perceptual gap [P-E $=-0.3139]$. The results in Tables 6 and 5 showed that the overall quality for each service dimension still has not met overseas Chinese and Taiwanese students' expectations. This implies that higher education universities still fall short in achieving desirable service quality from overseas Chinese and Taiwanese students' perspective.

\section{Conclusion and Implications}

The findings revealed that there is a clear gap between overseas students' expectations and perceptions of educational services in Scottish universities. The areas that were perceived to be less satisfactory to students are; staff's willingness to help overseas students, staff's sincerity in resolving students' problems, and quality of feedback given by academics. Our results in this regard are generally similar to those of previous research and industry reports. We believe that the success of higher education service in Scotland might be dependent on the way that the Scottish universities will respond to the 'perception-expectation' gap that was expressed by overseas students. We also believe that the sustainability of the growth rate of overseas students attending Scottish universities requires some improvement in educational service quality and better understanding of cross-cultural differences.

Mead (2005) and Furrer et al. (2000) suggest that cultural diversity provides several opportunities and challenges, which if they are analysed carefully, many economic benefits can be gained. Therefore, Scottish HE institutions may have to think about the extent of standardization-customization of their services to satisfy the varying expectations of overseas versus home students. It is also essential for Scottish universities to realize that the higher education market is made up of both local and overseas students, and that satisfying their expectations will probably generate positive word-of-mouth communications.

One of the service gaps found in this study is the lack of prompt responses given by staff to students. Higher education institutions should therefore deploy their staff in an efficient manner, for which good service can be delivered. Looy, Dierdonck and Gemmel (1998) suggest that planning and scheduling of service staff should be integrated with the management of other resource and positioned within a framework of manpower planning.

Few limitations must be acknowledged in this study. Due to constraints of time and cost, only quantitative research was used. It is suggested that a more intensive and flexible qualitative research regime can be employed to further probe student' insights, and can also inform more specific content in quantitative research. This study investigated only overseas Chinese and Taiwanese students' expectations and perceptions. Future research should consider other nationalities of foreign students to gain broader understanding of overseas students' concerns/requirements. On-line learning is growing in prosperity, and the service quality for this type of education should also be investigated. This study was done in five universities in Scotland which might affect the generalisability of the results to other countries.

\section{References}

Aldridge, S., \& Jennifer, R. (1998). Measuring Customer Satisfaction in Higher Education. Quality Assurance in Education, 6(4), 197-204. http://dx.doi.org/10.1108/09684889810242182

Arnould, E., Price, L., \& Zinkhan, G. (2002). Consumers (2nd ed.). McGraw Hill.

Bitner, M. J. (1990). Evaluating Service Encounters: The Effects of Physical Surroundings and Employee Responses. Journal of Marketing, 54(2), 69-82. http://dx.doi.org/10.2307/1251871

Buttle, F. (1995). SERVQUAL: Review, Critique, Research Agenda. European Journal of Marketing, 30, 8-32. http://dx.doi.org/10.1108/03090569610105762

Centeno, E., Harker, M., Ibrahim, E., \& Wang, L. W. (2008). What is Postgraduate Marketing Education for? Observations from the UK. European Business Review, 20(6), 547-566. http://dx.doi.org/10.1108/09555340810913557

Churchill, G. A. Jr., Brown, T. J., \& Paul, J. P. (1993). Improving the Measurement of Service Quality. Journal of Retailing, 69(1), 127-139. http://dx.doi.org/10.1016/S0022-4359(05)80006-5

Coulthard, J. M. (2004). Measuring Service Quality - A Review and Critique of Research using SERVQUAL. International Journal of Market Research, 46(4), 479-497.

Cronin, J. J., \& Steven, A. T. (1992). Measuring Service Quality: A Re-examination and Extension. Journal of Marketing, 56, 55-68. http://dx.doi.org/10.2307/1252296

Cronin, J. J., \& Steven, A. T. (1994). SERVPERF Versus SERVQUAL: Reconciling Performance - based and 
perception - Minus - expectations Measurement of Service Quality. Journal of Marketing, 58, 125-131. http://dx.doi.org/10.2307/1252256

Cuthbert, P. (1996). Managing service quality in HE: Is SERVQUAL the Answer? Part 1. Managing Service quality Bedford, 6(3), 11-16. http://dx.doi.org/10.1108/09604529610109701

Furrer, O., Shaw-Ching, B. L., \& Sudharshan, D. (2000). The Relationships Between Culture and Service Quality Perceptions. Journal of Service Research, 2(4), 355-371. http://dx.doi.org/10.1177/109467050024004

Guilford, J. P. (1978). Fundamental Statistics in Psychology and Education (6th ed.). McGraw-Hill.

Hill, F. (1997). The implication of service quality theory for British Higher Education: An Exploratory Longitudinal Study. Journal of General Education, 46(3), 207-231.

Hoffman, K. D., \& Bateson, J. E. G. (1997). Essentials of Services Marketing. Fort Worth: Dryden Press.

Kerlin, C. A. (2000). Measuring Student Satisfaction with the Service Processes of Selected Student Educational Support Services at Everett Community College. (Unpublished doctoral dissertation). The Oregon State University, Oregon.

Kumar, V., Aaker, D. A., \& Day, G. S. (2002). Essentials of Marketing Research (2nd ed.). John Wiley and Sons, INC.

Lehtinen, U., \& Lehtinen, J. R. (1982). Service Quality: A Study of Quality Dimensions. (Unpublished working paper). Helsinki: Service Management Institute, Finland.

Looy, B. V., Dierdonck, R. V., \& Gemmel, P. (1998). Services Management: An Integrated Approach. Financial Times Pitman Publishing.

Malhotra, N. K. (2004). Marketing Research: An Applied Orientation (4th ed.). Pearson Education, Inc.

Mead, R. (2005). International Management: Cross Culture Dimensions (3rd ed.). Blackwell.

Parasuraman, A., Zeithaml, V. A., \& Berry, L. L. (1985). A Conceptual Model of Service Quality and its Implications for Future Research. Journal of Marketing, 49, 41-50. http://dx.doi.org/10.2307/1251430

Parasuraman, A., Zeithaml, V. A., \& Berry, L. L. (1988). SERVQUAL: A Multiple Item Scale for Measuring Consumer Perceptions of Service Quality. Journal of Retailing, 64(1), 14-40.

Parasuraman, A., Zeithaml, V. A., \& Berry, L. L. (1994). Reassessment of Expectations as a Comparison Standard in Measuring Service Quality: Implications for Further Research. Journal of Marketing, 58, 111-124. http://dx.doi.org/10.2307/1252255

Ruby, C. A. (1996). Assessment of Student Satisfaction with Selected Student Support Services Using the SERVQUAL Model of Customer Satisfaction. (Unpublished doctoral dissertation). Ohio University, USA.

Scottish Higher Education founding council. (2003a). Baseline report part 7, International students and links. Retrieved from http://www.shefc.ac.uk

Scottish Higher Education founding council. (2003b). Survey of Student Experience. Retrieved April 2003 from http://www.shefc.ac.uk

Scottish Higher Education founding council. (2005). Baseline report 1st update. Retrieved form http://www.shefc.ac.uk

Seymour, D. T. (1992). It's All in the Attitude, on Q: Causing Quality in Higher Education. American Council on Education and Macmillan Publishing Company, pp. 126-141.

Soutar, G. N., McNeil, M., \& Lim, K. (1996). Service Quality in Educational Institutions: A foreign Student View. Journal of Marketing for Higher Education, 7(2), 85-94. http://dx.doi.org/10.1300/J050v07n02_07

Suba, K. G. (1997). School Quality Satisfaction Survey: Assessing Expectation for and Satisfaction with Quality of Education Provided by Elementary Schools. (Unpublished Doctoral Dissertation). The Pennsylvania State University, Pennsylvania.

Tomkovick, C., Al-Khatib, J., Baradwaj, B. G., \& Jones, S. I. (1996). An Assessment of the Service Quality Provided to Foreign Students at US Business Schools. Journal of Education for Business, 61(3), 130-135. http://dx.doi.org/10.1080/08832323.1996.10116772

Treasury Committee. (2005). Impact of China on the World \& UK Economy. University UK. Retrieved from http://www.universitiesuk.ac.uk 
Zeithmal, V. A., Berry, L. L., \& Parasuraman, A. (1993). The Nature and Determinants of Customer Expectations of Service. Journal of the Academy of Marketing Science, 21(1), 1-12. http://dx.doi.org/10.1177/0092070393211001

Zikmund, W. G. (1997). Exploring Marketing Research (6th ed.). The Dryden Press. 